$$
\begin{array}{ccccccccc}
\multicolumn{10}{c}{\text { 大阪船員保険病院外科 }} \\
\text { 石 } & \text { 田 } & \text { 秀 } & \text { 之 } & \text { 主 } & \text { 島 } & \text { 洋一郎 } & \text { 渡 辺 康 則 } \\
\text { 中 } & \text { 口 } & \text { 和 } & \text { 則 } & \text { 甲 } & \text { 利 幸 } & & &
\end{array}
$$

\title{
A Case Report of Malignant Intestinal Obstruction Effectively Treated with Octreotide
}

\author{
Hideyuki ISHIDA, Yoichiro NUSHIJIMA, Yasunori WATANABE, \\ Kazunori NAKAGUCHI and Toshiyuki KABUTO \\ Department of Surgery, Osaka Seamen's Insurance Hospital
}

\begin{abstract}
オクトレオチドは持続性のソマトスタチンアナログ製剂である。症例は 74 歳, 男性。原発部位不明の癌性腹膜 炎で保存的に加療していた。嘔気・嘔吐·全身倦怠のため入院となった。腹部CT検査, 上部内視鏡検査で腸閉塞 と診断した。胃管チューブを留置して，絶飲・絶食とした。糖尿病のため輸液内にインシュリンを混注した。本 人の希望で胃管チューブを抜去したところ, 嘔気が持続し， 1 日に数回嘔吐するため，オクトレオチド $300 \mu \mathrm{g} / \mathrm{day}$ の持続皮下注を始めた。嘔気は消失し, 嘔吐は激減した。胃管チューブを留置することなく, 後日飲水が可能と なった。一方，オクトレオチド投与後意識障害，尿失禁あり。血糖值は38であった。オクトレオチドは末期癌患 者の消化管症状に有効であるが，インシュリン使用中の患者では低血糖を生じることがあるので十分な注意が必 要である。
\end{abstract}

索引用語：オクトレオチド (octreotide acetate), 悪性疾患による消化管閉塞 (malignant intestinal obstruction), 低血糖 (hypoglycemia)

\section{はじめに}

オクトレオチドは持続性のソマトスタチンアナ ログ製剂である。本邦では2004年10月に「進行・ 再発癌患者の緩和医療における消化管閉塞に伴う 消化器症状の改善」という効能追加が認められた。 今回，私たちは原発部位不明の癌性腹膜炎による 腸閉塞症状に対してオクトレオチドを用いたとこ ろ，著明な症状の改善とともに，低血糖をきたし た症例を経験したので, 若干の文献的考察を加え て報告する。

\section{症例}

症 例：74歳, 男性。
主 訴：嘔気, 嘔吐, 全身倦怠感。

家族歴：特記すべきことなし。

既往歴：71歳時より心房細動, 糖尿病で加療中。 初回入院時, インシュリンを朝 26 単位, 夕14単位 皮下注。

現病歴：平成16年 7 月胆石胆囊炎との診断で開 腹した。少量の腹水と腹膜に小結節あり。迅速病 理診断でadenocarcinomaとわかり, 肝床部合併 切除を伴う胆囊摘出術を施行した。術中の検索で は胆囊以外に所見を認めず。病理組織検査で胆囊 はxanthogranulomatous cholecystitis, 腹膜の小 結節は中分化一低分化adenocarcinomaであっ た。内視鏡および画像検査で, 胃・大腸・肺など に病巣を認めず。原発部位不明の癌性腹膜炎と診 


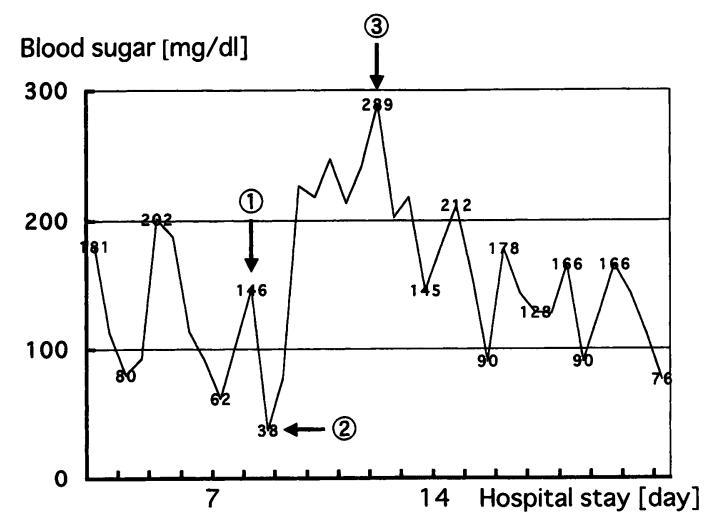

Fig. 1 Change of the serum level of blood sugar. After adminisration of Octreotide (1), the patient suffered from hypoglycemia and we stopped to prescribe insulin (2)). Then, the serum level of blood sugar recovered and we re-prescribed insulin with one-third of dose to the patient (3)).

断し, UFTを $300 \mathrm{mg}$ 分 3 毎食後で投与した。UFT は下痢および不定愁訴のために中断し，保存的に 加療していた。

今回, 嘔気・嘔吐・全身倦急感が増強し, 平成 17 年 2 月入院となった。

入院時現症 : 身長 $162 \mathrm{~cm}$, 体重 $42 \mathrm{~kg}$ ，血圧 $103 /$ $63 \mathrm{mgHg}$, 脈拍 $66 /$ 分・不整, 体温 $36.0^{\circ} \mathrm{C}$ 。呼吸音 は清，心雑音は聴取せず。

入院時血液検查所見：一般血液生化学検查は WBC : $7000 / \mathrm{mm}^{3}, \mathrm{Hb}: 16.7 \mathrm{~g} / \mathrm{dl}, \mathrm{Ht}: 48.3 \%$, Plt : $16.7 \times 10^{4} / \mathrm{mm}^{3}$ で脱水状態と考えられた。 CRP : $3.06 \mathrm{mg} / \mathrm{dl}, \mathrm{LDH}: 268 \mathrm{IU} / \mathrm{l}$, 総ビリルビ ン : $1.4 \mathrm{mg} / \mathrm{dl}$, 尿素窒素 : $46.3 \mathrm{mg} / \mathrm{dl}$ と軽度上昇 していた。腫瘍マーカーはCEA $: 4.7 \mathrm{ng} / \mathrm{ml}$ と正常 範囲で，CA19-9：803U/mlと高值であった。

腹部CT検查所見：腹水あり。胃から十二指腸に かけて拡張している。肝内胆管に軽度拡張あり。

上部内視鏡検查所見：胃内に緑色胆汁が貯留し ている。十二指腸乳頭部が腫瘍様に腫大している。 乳頭部より末梢側に食物残渣を多量認める。

以上より癌性腹膜炎による十二指腸末梢から空 腸起始部での腸閉塞と診断した。

経 過：胃管チューブを留置して, 絶飲・絶食 とした。アミノトリパ1号中にノボリン Rを 12 単 位混注して，1 日 2 本投与した。血糖は62 202(中
央值112)であった。本人の希望で胃管チューブを 抜去したところ，嘔気が持続し，1日に数回嘔吐 するため, 第 9 病日の昼からオクトレオチド（サ ンドスタチン®) $300 \mu \mathrm{g} / \mathrm{day}$ の持続皮下注を始め た。嘔気は消失し, 嘔吐は激減した。胃管チュー ブを留置することなく, 後日飲水が可能となった。 一方, 第 10 病日の早朝, 意識障害, 尿失禁あり。 血糖は38と低下しており, ブドウ糖を静注した。 輸液内のインシュリンを中止したところ，血糖は 上昇した。第13病日よりアミノトリパ1号中にノ ボリン $\mathrm{R}$ を 4 単位混注した。その後血糖は 76〜212（中央值143）となった（Fig. 1)。本人の 希望で第23病日より牛乳，第37病日より流動食を 開始したが, 捸取量は少量かつ不定であった。経 口捸取により嘔気が増悪するため, 補液とサンド スタチン®を継続した。第51病日に他病死した。

\section{考察}

オクトレオチド (サンドスタチン®) は持続性の ソマトスタチンアナログ製剂である。作用部位は 下垂体, 膵臓, 消化管, 甲状腺, 副腎, 腎臓と多 岐にわたる。基本的な薬理作用をTable 1 に示 す1)。近年欧米より消化管閉塞に対するオクトレ オチドの有効性が報告され ${ }^{233)}$, 本邦でも難治性の 下痢や消化管閉塞による嘔気・嘔吐を緩和する作 用があることが確認された ${ }^{4)}$ )。その結果, サンド スタチン®に2004年10月,「進行・再発癌患者の緩 和医療における消化管閉塞に伴う消化器症状の改 善」に効能追加が認められた。

オクトレオチドの半減期は100分で, 効果の発現 は早く, 蓄積の少ない薬物である。投与方法は上 記適応の場合, 持続皮下注入による単独投与が示 されている。文献的には持続静注や12時間おきの 皮下注でも同等の効果があり, モルヒネ, ブプレ ノルフィン，ハロペリドール，メトクロプラミド などと混注してもその効果は変わらないと報告さ れている7)8。

消化管閉塞では腸内容が増大して腸管が拡張 し, 腸管の表面積が増大する結果, 水や電解質を より多く分泌して, さらに腸管の拡張を増大させ るという“悪性サイクル”を形成することが指摘 されている4)。オクトレオチドは腸上皮細胞レべ 
Table 1 Principal actions of octreotide

\begin{tabular}{|c|c|c|c|}
\hline Organ & Function & Target & Action \\
\hline \multirow[t]{2}{*}{ Pituitary } & & Growth hormone (GH) & inhibition of basal and stimulated secretion \\
\hline & & Thyroid stimulating hormone (TSH) & inhibition of basal and stimulated secretion \\
\hline \multirow[t]{4}{*}{ Pancreas } & Endocrine & Insulin & inhibition of basal and stimulated secretion \\
\hline & & Glucagon & inhibition of basal and stimulated secretion \\
\hline & & Pancreatic polypeptide & inhibition of secretion \\
\hline & Exocrine & Bicarbonates and Enzyme & inhibition of secretion \\
\hline \multirow[t]{7}{*}{$\begin{array}{l}\text { Gastro- } \\
\text { intestinal } \\
\text { tract }\end{array}$} & Endocrine & $\begin{array}{l}\text { Gastrin, Cholecytokinin, Vasoactive intestinal peptide, } \\
\text { Gastric inhibitory polypeptide, Motilin, Enteroglucagon } \\
\text { and Neurotensin }\end{array}$ & inhibition of secretion \\
\hline & Exocrine & $\begin{array}{l}\text { Gastric acid, Pepsin, Intrinsic factor, Colonic fluid and } \\
\text { Bile }\end{array}$ & inhibition of secretion \\
\hline & Motor activity & $\begin{array}{l}\text { Gastric emptying, Gallbladder contraction and Small } \\
\text { intestinal segmentation }\end{array}$ & inhibition \\
\hline & Absorption & $\begin{array}{l}\mathrm{Ca}^{2+}, \text { Glucose, Galactose, Glycerol, Fructose, Xylose, } \\
\text { Lactose, Amino acids, Triglycerides and Water }\end{array}$ & decreases rate of absorption \\
\hline & Blood flow to gut & Mesenteric blood flow & decreases \\
\hline & & Vascular resistance & increases \\
\hline & Trophic function & Mucosal cell proliferation & decreases \\
\hline \multirow[t]{2}{*}{ Thyroid } & & Thyroxine (T4), Tri-iodothyronine (T3) & inhibition of release \\
\hline & & Calcitonin & inhibition of secretion \\
\hline \multirow[t]{2}{*}{ Adrenal } & & Angiotensin II-stimulated aldosterone and & inhibition of secretion \\
\hline & & Acethylcholine-stimulated medullary Catecholamine & \\
\hline \multirow[t]{2}{*}{ Kidneys } & & Renin & inhibition of release \\
\hline & & Antidiuretic hormone-mediated water absorption & inhibition \\
\hline
\end{tabular}

ルに作用し，水や電解質の分泌を抑制し，それら の吸収を促進するので，この悪性サイクルを断ち 切ることができると考えられている。オクトレオ チドはすでに胃管を扱入している末期癌の消化管 閉塞に対して，胃管抜去を可能にし，抜去後も悪 心・嘔吐に対しても有用な薬剤であることが報告 されている6)。本症例でもオクトレオチド投与後, 悪心は消失し, 嘔吐が激減して, 後日飲水が可能 となった。従来，末期癌患者の消化管閉塞に対す る原因治療は手術や抗癌剂で, 症状をコントロー ルする治療は胃管チューブやイレウスチューブに よる減圧であり，いずれも苦痛を伴う選択肢であ った。オクトレオチドは消化管閉塞に対する原因 治療となり，同時に症状をコントロールできるの で, 今後末期癌患者の消化管閉塞に対する有用な 選択肢になると考える。

オクトレオチドを消化管閉塞に用いた場合の副 作用について, 口渇, 注射部位の疼痛, 皮膚反応 が報告されている。投与中止によるリバウンドは 報告されていない5)。オクトレオチドが血糖值に 及ばす影響は複雑である。オクトレオチドは成長 ホルモンとグルカゴンの分泌を抑制するととも
に，膵外分泌と消化管運動を抑制して糖質吸収の 遅延を生じることで血糖值を下げる反面, インシ ユリンの分泌を抑制して血糖值を上げるので，総 合的な結果として血糖値が上がるのか, 下がるの か, 変わらないのかは個々の症例で一定していな い。サンドスタチン®の総合製品情報でもインシュ リンは併用注意となっており, 血糖降下作用の増 強による低血糖症状，または減弱による高血糖症 状があらわれることがあると記載されている。文 献的にも同様の記述が多くみられたが, 橋本ら ${ }^{9}$ はオクトレオチドをインシュリン使用中の糖尿病 患者に併用すると, 成長ホルモンの分必低下に伴 い,インシュリンの血糖降下作用が強くあらわれ， 低血糖を生じることがあると報告していた。著者 らはインシュリン使用中の患者では低血糖になる ことの方が深刻であるので, 今後オクトレオチド との併用に際してはインシュリンを中止する， あ るいは十分に減量してfollow-upした方が賢明で あると考える。

\section{結 語}

今回私たちは癌性腹膜炎による腸閉塞に対して 
オクトレオチドを用い, 著明な症状の改善ととも に，低血糖をきたした症例を経験した。オクトレ オチドは末期癌患者の消化管症状に有効である が，インシュリン使用中の患者では低血糖を生じ ることがあるので十分な注意が必要である。

\section{参考文献}

1) Chanson P, Timsit J, Harris AG : Clinical Pharmacokinetics of Octreotide. Therapeutic Applications in Patients with Pituitary Tumors. Clin Pharmacokinet 25 : 375-391, 1993

2) Mercadante S, Spoldi E, Caraceni $A$, et al: Octreotide in relieving gastrointestinal symptoms due to bowel obstruction. Palliat Med 7 : 295-299, 1993

3) Khoo D, Hall E, Motson R, et al : Palliation of Malignant Intestinal Obstruction Using Octreotide. Eur J Cancer 30A : 28-30, 1994
4）前野 宏, 池永昌之, 恒藤 暁他：末期癌患者の 消化管閉塞に対するオクトヌクレオチドの効果. 死の臨 $19: 49-52,1996$

5）古宇田裕子, 荒井和子, 飯塚友道：末期がん患者 の消化管閉塞におけるオクトヌクレオチドの使 用方法の検討. ターミナルケア $9 ： 217-222,1999$

6）志真泰夫, 山口研成, 宮田佳典他：末期癌患者に おける消化管閉塞に伴う消化器症状に対する Octreotide Acetateの臨床経験. 癌と化療 31 : 1377-1382, 2004

7) Marie $\mathrm{TF}$ : The physiology of somatostatin and its synthetic analogue, octreotide. Eur J Palliative Care $1: 20-22,1993$

8) Mercadante $S$ : The Role of Octreotide in Palliative Care. J Pain Sympt Manage $9: 406-411$, 1994

9）橋本浩三：成長ホルモン分泌抑制薬（サンドスタ チン). Medicina $39: 344-345,2002$ 